\title{
Sequential antibody changes following ulcerative herpetic keratitis
}

\author{
K R WILHELMUS, S DAROUGAR, T FORSEY, AND J D TREHARNE \\ From the Subdepartment of Virology, Institute of Ophthalmology, London
}

SUMMARY Blood and tear levels of immunoglobulins against herpes simplex virus (HSV) were examined in 28 patients with dendritic keratitis over a period of 28 days. By means of an indirect micro-immunofluorescent technique blood and tear HSV IgG were detected, but neither circulating HSV IgM nor local HSV IgA were found. Over a four-week interval non-diagnostic fluctuations of HSV IgG occurred in most patients, though seven (25\%) developed a rising blood IgG titre. Tear IgG appeared to be an exudate from blood. HSV was isolated from $68 \%$ of corneal swabbings and $11 \%$ of conjunctival swabbings. This study provides guidelines for laboratory testing in recurrent herpetic keratitis.

Initial immune responses during primary herpes simplex virus (HSV) ocular infection include lymphocyte sensitisation with macrophage activation and the development of specific HSV IgM antibodies followed by HSV IgG and IgA antibodies. Subsequently the IgG titre may persist for a long period and is useful in seroepidemiological surveys for estimating a population's exposure to HSV. But despite circulating HSV antibodies some individuals later develop recurrent keratitis. To determine if recurrent herpetic eye disease may be associated with an anamnestic humoral immune response we have prospectively evaluated blood and tear HSV antibody titres from patients with dendritic keratitis.

\section{Materials and methods}

Specimen collection. Clinical specimens were collected from patients with typical dendritic corneal ulceration attending Moorfields Eye Hospital, London. Whole blood and tears were collected on cellulose sponges' from each patient on the day of presentation, after 14 days, and after 28 days. At the time of first examination, after the eye was anaesthetised with benoxinate solution conjunctival specimens were taken by rubbing a dry cotton-tipped swab across the everted upper and lower conjunctivae. Corneal epithelial debridement was performed with a sterile cotton-tipped applicator removing the

Correspondence to Dr K R Wilhelmus, Cullen Eye Institute, 6501 Fannin Street, Houston, Texas 77030 , USA. loosened corneal epithelial cells at the ulcer edge. Patients received 3\% acyclovir ointment five times daily and $1 \%$ atropine eye drops twice daily until the corneas were healed.

Viral isolation. Conjunctival and corneal swabbings were placed into individual capsules containing $1.2 \mathrm{ml}$ of $2 \mathrm{SP}$ transport medium ${ }^{2}$ with $3 \%$ fetal calf serum, stored in a liquid nitrogen refrigerator $\left(-180^{\circ} \mathrm{C}\right)$, and transferred to the laboratory, where they were stored in a $-70^{\circ} \mathrm{C}$ refrigerator. Each clinical specimen was inoculated into two tubes containing monolayers of HEp 2 cells in accordance with the method described elsewhere. ${ }^{34}$ Viral isolates were identified by a fluorescent antibody technique.

Serology. Each saturated sponge containing whole blood or tears was placed in a tightly stoppered dry capsule, transferred to the laboratory, and stored at $-20^{\circ} \mathrm{C}$. Blood and tear specimens were tested for type specific antibodies to HSV by an indirect microimmunofluorescent technique. ${ }^{5}$ HSV IgG and IgM were sought in blood at starting dilutions of 1:16 and $1: 8$ respectively. Tears were tested for HSV IgG and IgA at a starting dilution of $1: 8$. Blood was also tested for HSV antibodies by the complement fixation technique.

\section{Results}

Twenty-eight patients with dendritic keratitis were studied, 11 females and 17 males, with an average age of 47 years (SD 15, range, 16-74). All healed within 10 days; four patients (cases 5, 12, 23, and 27) later 
developed disciform keratouveitis. HSV type 1 was isolated from $3(11 \%)$ of the conjunctival swabbings and from $19(68 \%)$ of the corneal debridement samples (Table 1). No HSV type 2 was isolated from these patients. The presence of a positive culture was not statistically associated with any clinical factor, including the duration of symptoms.

Serological results for each patient are listed in Table 1. Antibodies in every case were specific for HSV-1, although low-level cross reactions with HSV-2 did sometimes occur. Type specific HSV IgM was not detected from any blood specimen. The reciprocal geometric mean titres of circulating HSV-1 IgG were 13 on day 0,9 on day 14 , and 8 on day 28 . Seven $(25 \%)$ of the patients developed a fourfold rise in circulating HSV IgG during the onemonth follow-up period. Seventeen $(61 \%)$ of the patients had no detectable blood HSV IgG on at least one of the three sampling days.

Type specific HSV IgA was not detected in the tears from any patient. HSV IgG was detected with a reciprocal geometric mean titre of 4 at day 0 , and 0.5 and 0 at days 14 and 28 respectively. The level of HSV IgG was always equal to or less than the corresponding blood HSV IgG. Only one patient showed a fourfold rise in tear antibody titre, and this was from a patient who also had a rise in blood antibody. Complement fixing HSV antibody was detected in 27 patients, and no significant fluctuation was noted (Table 1).

\section{Discussion}

Early work on the antibody response following HSV infection provided the first clues that the virus can persist endogenously after the primary infection. Burnet and Williams ${ }^{6}$ postulated that the latent virus conveys 'a constant or intermittent antigenic stimulus which maintains a circulating antibody at a high level.' Prospective studies on the antibody response during the four weeks following recurrent mucocutaneous herpetic disease confirmed that circulating HSV antibody levels usually remain relatively constant,,$^{7-12}$ though significant fluctuations of a fourfold or greater rise in antibody titre occurred occasionally. ${ }^{79}$ Moreover, asymptomatic recurrent HSV shedding does not usually stimulate a rise in antibody titre, ${ }^{13}$ but endogenous viral reactivation can sometimes contribute to increases in $\operatorname{IgG}, \operatorname{IgM}$, or $\operatorname{IgA}$ titres. ${ }^{14}$ Similar studies on herpetic ocular disease showed that serological testing is useful to confirm a primary infection but noted that 'recurrent attacks of

Table 1 Relation of HSV isolates to blood and tear reciprocal antibody titres in patients with dendritic keratitis

\begin{tabular}{|c|c|c|c|c|c|c|c|c|c|c|c|c|c|c|c|}
\hline \multirow{2}{*}{\multicolumn{2}{|c|}{ Patient Age }} & \multirow{3}{*}{$\begin{array}{l}\text { Sex } \\
\text { F }\end{array}$} & \multirow{3}{*}{$\begin{array}{l}\text { Previous } \\
\text { attack } \\
\mathrm{Y}\end{array}$} & \multirow{3}{*}{$\begin{array}{l}\text { Duration of } \\
\text { symptoms } \\
\text { (days) }\end{array}$} & \multirow{3}{*}{$\begin{array}{l}\text { Conjunctival } \\
\text { culture }\end{array}$} & \multirow[t]{2}{*}{$\begin{array}{l}\text { Corneal } \\
\text { culture }\end{array}$} & \multicolumn{3}{|c|}{$\begin{array}{l}\text { HSV-I blood IF } \\
\text { IgGon day: }\end{array}$} & \multicolumn{3}{|c|}{$\begin{array}{l}\text { HSV-I tear IF } \\
\text { IgGon day: }\end{array}$} & \multicolumn{3}{|c|}{$\begin{array}{l}\text { HSV blood CF } \\
\text { Ig on day: }\end{array}$} \\
\hline & & & & & & & 0 & 14 & 28 & 0 & 14 & 28 & 0 & 14 & 28 \\
\hline 1 & 69 & & & & & - & 0 & 0 & 0 & 0 & 0 & 0 & 20 & 40 & 40 \\
\hline 2 & 64 & $\mathbf{F}$ & $\mathbf{N}$ & 3 & - & + & 0 & 0 & 16 & 0 & 0 & 0 & 20 & 40 & 20 \\
\hline 3 & 55 & $\mathbf{M}$ & $\mathrm{Y}$ & 2 & - & + & 0 & 0 & 32 & 0 & 0 & 0 & 20 & 20 & 20 \\
\hline 4 & 16 & $\mathbf{F}$ & $\mathbf{N}$ & 1 & + & + & 0 & 16 & 0 & 0 & 0 & 0 & 0 & 0 & 0 \\
\hline 5 & 60 & $\mathbf{M}$ & $\mathbf{Y}$ & 1 & - & - & 0 & 16 & 16 & 0 & 0 & 0 & 20 & 20 & 10 \\
\hline 6 & 42 & $\mathbf{M}$ & $\mathbf{N}$ & 2 & - & + & 0 & 32 & 16 & 0 & 16 & 0 & 20 & 20 & 10 \\
\hline 7 & 74 & $\mathbf{M}$ & $\mathrm{Y}$ & 1 & - & - & 0 & 64 & 32 & 0 & 0 & 0 & 20 & 40 & 20 \\
\hline 8 & 31 & $\mathbf{M}$ & $\mathrm{Y}$ & 1 & - & + & 16 & 0 & 0 & 16 & 0 & 0 & 40 & 40 & 40 \\
\hline 9 & 36 & $\mathbf{F}$ & $Y$ & 1 & - & - & 16 & 16 & 16 & 8 & 0 & 0 & 20 & 20 & 20 \\
\hline 10 & 40 & $\mathbf{M}$ & $\mathbf{N}$ & 1 & - & + & 16 & 16 & 16 & 0 & 0 & 0 & 20 & 20 & 20 \\
\hline 11 & 53 & $\mathbf{M}$ & $\mathrm{Y}$ & 1 & - & + & 16 & 32 & 0 & 16 & 0 & 0 & 80 & 80 & 80 \\
\hline 12 & 56 & $\mathbf{M}$ & $\mathrm{Y}$ & 1 & - & + & 16 & 32 & 32 & 8 & 0 & 0 & 20 & 20 & 20 \\
\hline 13 & 40 & $\mathbf{M}$ & $\mathbf{N}$ & 2 & - & + & 16 & 32 & 32 & 16 & 0 & 0 & 80 & 80 & 80 \\
\hline 14 & 73 & $\mathbf{M}$ & $Y$ & 2 & - & + & 16 & 64 & 64 & 0 & 0 & 0 & 80 & 80 & 80 \\
\hline 15 & 59 & $\mathrm{~F}$ & $\mathrm{Y}$ & 1 & - & - & 32 & 0 & 0 & 0 & 0 & 0 & 10 & 10 & 10 \\
\hline 16 & 41 & $\mathbf{F}$ & $\mathbf{N}$ & 2 & - & + & 32 & 0 & 0 & 0 & 0 & 0 & 40 & 40) & 40 \\
\hline 17 & 45 & $\mathbf{M}$ & $Y$ & 1 & - & + & 32 & 0 & 16 & 0 & 0 & 0 & 20 & 20 & 10 \\
\hline 18 & 54 & $\mathbf{F}$ & $Y$ & 2 & - & + & 32 & 0 & 16 & 16 & 0 & 0 & 80 & 80 & 40 \\
\hline 19 & 54 & $\mathbf{F}$ & $\mathbf{N}$ & 2 & - & + & 32 & 16 & 16 & 0 & 0 & 0 & 10 & 10 & 10 \\
\hline 20 & 27 & $\mathbf{M}$ & $\mathbf{N}$ & 1 & - & + & 32 & 16 & 16 & 0 & 0 & 0 & 40 & 40 & 40 \\
\hline 21 & 23 & $\mathbf{F}$ & $Y$ & 1 & - & - & 32 & 32 & 16 & 0 & 0 & 0 & 20 & 20 & 20 \\
\hline 22 & 53 & $\mathbf{M}$ & $\mathrm{Y}$ & 2 & - & - & 32 & 64 & 32 & 8 & 0 & 0 & 40 & 40 & 40 \\
\hline 23 & 35 & $\mathbf{F}$ & $\mathbf{N}$ & 2 & + & + & 64 & 0 & 64 & 0 & 0 & 0 & 40 & 40 & 40 \\
\hline 24 & 42 & $\mathbf{M}$ & $Y$ & 1 & - & + & 64 & 32 & 0 & 8 & 0 & 0 & 40 & 40 & 40 \\
\hline 25 & 70 & $\mathbf{M}$ & $\mathbf{N}$ & 1 & + & + & 64 & 32 & 0 & 0 & 0 & 0 & 20 & 20 & 20 \\
\hline 26 & 42 & $\mathrm{~F}$ & $N$ & 1 & - & + & 64 & 32 & 0 & 8 & 0 & 0 & 80 & 80 & 80 \\
\hline 27 & 40 & $\mathbf{M}$ & $\mathbf{Y}$ & 1 & - & - & 64 & 32 & 16 & 0 & 0 & 0 & 20 & 20 & 20 \\
\hline 28 & 45 & $\mathrm{M}$ & $\mathbf{Y}$ & 1 & - & - & 128 & 16 & 16 & 8 & 0 & 0 & 160 & 80 & 80 \\
\hline
\end{tabular}

$\mathrm{Y}=$ yes. $\mathrm{N}=$ no. $+=$ Positive.$-=$ Negative. $\mathrm{IF}=$ immunofluorescent $. \mathrm{CF}=$ complement - fixing. 
herpetic infection are not associated with changes in the antibody level before, during, or after these episodes. ${ }^{15}$

In the present series 28 patients with dendritic keratitis were studied over four weeks. Blood and tear HSV IgG could be detected, but neither circulating HSV IgM nor local HSV IgA were found. Seven $(25 \%)$ of the patients developed a fourfold rise in blood HSV-1 IgG titre during the follow-up period. One patient had no detectable blood HSV-1 antibody at any time, and $61 \%$ had no detectable tear HSV-1 antibody. Because the tear IgG level was equal to or less than the corresponding blood IgG titre, tear antibody appears to be an exudate from blood. Cross reacting antibodies to HSV type 2 were occasionally detected.

The results of this study may provide guidelines to the role of laboratory testing in herpetic keratitis. Firstly, while recurrent herpetic keratitis does not usually cause a rise in antibody titre, $25 \%$ of our patients with dendritic keratitis did develop a significant elevation of immunofluorescent IgG antibody. Secondly, circulating HSV IgM was not detected following dendritic keratitis. An elevated HSV IgM titre would be more suggestive of a primary infection than a recurrence, though some studies have found individuals with a persistent level of HSV IgM antibodies between or at the time of clinical recurrences. ${ }^{16}$ Thirdly, after they had been treated, some seropositive individuals reverted to apparent seronegativity as measured by the indirect microimmunofluorescent technique, though complementfixing antibodies persisted. Prior HSV exposure may need to be assessed either by different serological assays or by repeated testing on an individual. We cannot explain why antibody levels occasionally became undetectable following an initially positive test in some patients. Fourthly, local production of HSV IgA is not apparently involved in recurrent keratitis, though other workers have found a rising tear $\operatorname{IgA}$ titire following dendritic keratitis. ${ }^{17}$

Finally, viral isolation from corneal debridement swabbings is useful to confirm the presence of HSV in patients with dendritic keratitis. Our study suggests that HSV can be isolated from approximately twothirds of patients with dendritic keratitis and that corneal epithelial debridement swabbings are more sensitive than conjunctival swabbings in detecting HSV.

The host factors that lead to viral shedding, clincal recurrences, and recovery remain obscure. Antibodies may be involved in controlling the latent HSV in the trigeminal ganglion ${ }^{18}$ but do not appear to confer protection against recurrences. Furthermore, while antibodies can combine to $\mathrm{Fc}$ receptors on virus infected cells, HSV spreads by direct cellular contact prior to the expression of sufficient virus-specific surface antigens. Cell-mediated immunity and production of interferon and other lymphokines may be more important in limiting the spread of HSV, and antiviral therapy could affect these immune responses. Further work remains to determine the effects of humoral and cellular immunity in the pathogenesis of recurrent herpetic ocular disease.

This study was supported by a grant from the Department of Health and Social Security through Moorfields Eye Hospital.

\section{References}

1 Darougar S, Treharne JD, Minassian D, El-Sheikh H, Dines RJ, Jones BR. Rapid serological test for diagnosis of chlamydial ocular infections. Br J Ophthalmol 1978; 62: 502-8.

2 Gordon FB, Harper IA, Quan AL, Treharne JD, Dwyer R St C, Garland JA. Detection of chlamydia (bedsonia) in certain infections in men. I. Laboratory procedures: comparison of yolk sac and cell culture for detection and isolation. J Infect Dis 1969; 120: 451-62.

3 Cubitt WD, McSwiggan DA, Thaker U, Darougar S. A comparison of the efficiency of human embryo intestine, Hep 2 cells, and human embryo kidney cells for the primary isolation of ophthalmic viruses. BrJ Ophthalmol 1981; 65: 546-8.

4 Darougar S, Gibson JA, Thaker U. Effect of centrifugation on herpes simplex virus isolation. J Med Virol 1981; 8: 231-5.

5 Forsey T, Darougar S. Indirect micro-immunofluorescence test for detecting type-specific antibodies to herpes simplex virus. J Clin Pathol 1980; 33: 171-6.

6 Burnet FM, Williams SW. Herpes simplex: A new point of view. Med J A ust 1939; i: 637-42.

7 Jawetz E, Allende MF, Coleman VR. Studies on herpes simplex virus. IV. The level of neutralizing antibodies in human sera. J Immunol 1952; 68: 655-61.

8 Scott TFM, Coriell L, Blank H, Burgoon CF. Some comments on herpetic infection in children with special emphasis on unusual clinical manifestations. J Pediatr 1952; 41: 835-43.

9 Dascomb HE, Adair CV, Rogers N. Serologic investigations of herpes simplex virus infections. J Lab Clin Med 1955; 46: 1-11.

10 Douglas Jr RG, Couch RB. A prospective study of chronic herpes simplex virus infection and recurrent herpes labialis in humans. J Immunol 1970; 104: 289-95.

11 Kurtz JB. Specific IgG and IgM antibody responses in herpessimplex-virus infections. J Med Microbiol 1974; 7: 333-41.

$12 \mathrm{Wu} J-S$, Yamanishi R, Kaneko M, Uchida Y. Serum complement-fixing antibody in herpetic ocular diseases. Nippon Ganka Gakkai Zasshi 1981; 85: 415-8.

13 Cesario TC, Poland JD, Wulff H, Chin TDY, Wenner HA. Six years experience with herpes simplex virus in a children's home. Am J Epidemiol 1969; 90: 416-22.

14 Ratner JJ, Sanford BA, Smith KO. A serological study of herpes simplex virus type 1 antibody over a 13-year period. Dermatology 1980; 161: 227-32.

15 Lennette EH, van Allen A. Laboratory diagnosis of herpetic infections of the eye. Am J Ophthalmol 1957; 43: 118-26.

16 Nahmias AJ, Shore SL, Del Buono I. Diagnosis by immunofluorescence of human viral infections with emphasis on herpes simplex viruses. In: Kurstak E, Morisset R, eds. Viral immunodiagnosis. New York: Academic Press, 1974: 157-71.

17 Kaneko M. Studies on antibodies in serum and tears from patients with herpes simplex keratitis. Nippon Ganka Gakkai Zasshi 1973; 77: 7-14.

18 Stevens JG, Cook ML. Maintenance of latent herpetic infections: an apparent role for anti-viral IgG. J Immunol 1974; 113: $1685-93$.

Accepted for publication 10 October 1985. 